\title{
Opinie o ceremoniale dyplomatycznym w Rosji na podstawie relacji uczestników poselstw Rzeczypospolitej w drugiej połowie XVII wieku
}

\begin{abstract}
Abstrakt: Celem artykułu jest przedstawienie sposobu przyjmowania misji dyplomatycznych Rzeczypospolitej w Rosji w drugiej połowie XVII wieku. Opierając się na przebiegu poselstw, ukazano, jak Rosjanie przyjmowali poselstwa dyplomatyczne w ich kraju, na co zwracali szczególną uwagę oraz jak starali się wpływać na tok rozmów. Podkreślono znaczenie, jakie wówczas przywiązywano do zachowania zasad ceremoniału dyplomatycznego.
\end{abstract}

Słowa kluczowe: audiencja, ceremoniał dyplomatyczny, dyplomacja, plenipotencja, poseł, przystaw, tytulatura

Pojęcie dyplomacji jest wieloznaczne. Używane bywa jako synonim polityki zagranicznej albo sposobu jej prowadzenia. Może też oznaczać proces, sztukę organizowania stosunków międzynarodowych poprzez negocjacje lub inne środki o charakterze pokojowym. Dyplomacja umożliwia sterowanie procesami międzynarodowymi w celu rozwiązywania sporów i problemów związanych np. $\mathrm{z}$ handlem, przestępczością, ochroną środowiska. Tym pojęciem określa się również ludzi zatrudnionych w służbie zagranicznej. Innymi słowy, jest ona instrumentem polityki zagranicznej ${ }^{1}$.

Dyplomacja realizuje swoje zadania poprzez rozmowy posłów, rokowania, korespondencję, zawieranie traktatów międzypaństwowych. Formy prowadzenia działalności dyplomatycznej, w tym zasady zachowania, precedencji, kształtowały się od

${ }^{1}$ B. Surmacz: Ewolucja współczesnej dyplomacji: aktorzy, struktury, funkcje. Lublin 2015, s. $25-37$. 
starożytności². Jedną z nich było przyjmowanie posłów obcych państw. Ceremoniał ich przywitania, pożegnania, porządek postępowania, jego sformalizowanie były realizowane w każdym państwie zgodnie z panującymi w nim obyczajami. Celem ceremoniału było okazanie szacunku reprezentantowi obcego państwa ${ }^{3}$, a jednocześnie ukazanie własnej silnej pozycji.

Ceremoniał dyplomatyczny obowiązujący w XVII-wiecznej Rosji kształtował się stopniowo od XVI do końca XVII wieku. Wówczas ukonstytuowała się odmienna od wzorów bizantyjskich i zachodnich etykieta obowiązująca na carskim dworze ${ }^{4}$. Jej elementami było drobiazgowe przestrzeganie tytulatury carskiej, głoszenie, że dynastia Rurykowiczów wywodzi się od cesarza Augusta oraz strzeżenie carskiego honoru ${ }^{5}$.Ze starożytnego pochodzenia dynastii panującej w Rosji dyplomacja rosyjska wywodziła wniosek, że wielu monarchów jest mniej dostojnych niż car. Za takich uważała władców Szwecji, Danii, Anglii. Za równorzędnego uznała zaś sułtana tureckiego $-z$ powodu starożytności dynastii oraz despotycznego charakteru władzy ${ }^{6}$.

Wydaje się, że pomimo licznych sporów o carską tytulaturę w Rzeczypospolitej nie doceniano powagi, z jaką podchodzono w Rosji do tego zagadnienia. W 1650 roku posłowie rosyjscy w Warszawie żądali, aby popełniający błędy w tytulaturze „za pomyłki gardłem był karany [...] niech go na pal wbiją”. Wyjaśnień, choć dość naiwnych, że błędy były przypadkowe i niezamierzone, nie przyjmowano do wiadomości. Potem stanowisko rosyjskie złagodniało, tym niemniej dalej był to drażliwy temat. W 1684 roku podczas negocjacji w Kadzyniu Rosjanie poruszyli sprawę przestrzegania tytułów carskich. Kiedy jeden z komisarzy, wojewoda trocki, roześmiał się z powodu ponownego omawiania tego tematu ${ }^{8}$, zareagował na to jeden z posłów rosyjskich, Romadanowski, mówiąc: „nie trzeba się na to śmiać, bo my przy honorach Carów naszych głowy położemy"'.

${ }^{2}$ E. Pietkiewicz: Protokół dyplomatyczny. Warszawa 1998, s. 7.

3 Ibidem, s. 52.

${ }^{4}$ S.W. Bachruszyn, S.D. Skazkin: Dyplomacja państw europejskich w XVII w. W: Historia dyplomacji do 1871 r. T. 1. Red. W.M. Chwostow et al. Warszawa 1973, s. 309.

${ }^{5}$ Ibidem, s. 310.

${ }^{6}$ K. Снолміска: Narodziny rosyjskiej doktryny państwowej. Zoe Paleolog - między Bizancjum, Rzymem a Moskwą. Kraków 2001, s. 328-329.

7 Biblioteka Książąt Czartoryskich (dalej: BCzart.), sygn. TN 144, rkps 178, s. 911, Relacya rozgoworu Wielkich Posłów Moskiewskich z panami Sentorami w Warszawie un Anno 1650, 20 marty.

${ }^{8}$ Archiwum Państwowe w Toruniu (dalej: APT), sygn. Kat II, XIII-32, k. 88v, Copia listu JMS Wdy. Poznańskiego do JMS Kanclerza WK, z Kadzynia 26 february 1684. Wojewodą trockim był Marcjan Ogiński. Zob. J. Perdenia: Rokowania polsko-rosyjskie w Kadzyniu w 1684 r. „Rocznik Naukowo-Dydaktyczny" 1968, 22, s. 74.

9 BCzart., sygn. TN 181, rkps 70, s. 358, Relacja Komissyi Kadzyńskiej Ro 1683 zaczętey, a Ro 1684 skończoney na seymie warszawskim Ro 1685 przy obecności stanów Rzplitey uczyniona, i do Metryki W.X.Litt. podana przez J: W. Jm Pana Krzysztofa Grzymułtowskiego wojewodę poznańskiego. 
Dbałość o stosowanie prawidłowej carskiej tytulatury była dla Rosjan sprawą najwyższej wagi. Podobnie walczyli o to, aby za granicą nie było żadnych świadectw poniesionych przez nich klęsk. Na przykład w czasie rozmów w Moskwie w 1672 roku Rosjanie zażądali wydania obrazów przedstawiających klęski Rosji w wojnie z Rzecząpospolitą w czasach Zygmunta III Wazy ${ }^{10}$. W 1677 roku posłowie rosyjscy zażądali usunięcia z Zamku Królewskiego w Warszawie obrazów ukazujących bitwę pod Kłuszynem. Strona polska uznała wówczas, że obrazy mogą być zdjęte dopiero po zawarciu pokoju wieczystego ${ }^{11}$.

W XVII wieku posłów Rzeczypospolitej można podzielić na posłów wielkich (legatus, orator) oraz mniejszych (ablegatus, internuntius). Różnice między nimi sprowadzały się do ceremoniału przyjęcia ich w obcym państwie oraz do wystawności poselstwa. Natomiast pod względem uprawnień i tytulatury polskich dyplomatów można podzielić na następujące grupy: posłów króla i Rzeczypospolitej zwanych wielkimi, komisarzy króla i Rzeczypospolitej, posłów króla, sekretarzy poselstw, rezydentów oraz posłów i komisarzy hetmana ${ }^{12}$. Posłom udającym się do Moskwy i Turcji w najważniejszych sprawach, np. zawarcia lub potwierdzenia traktatów pokojowych, przysługiwał tytuł „wielki poseł” ${ }^{13}$. Korespondencja dyplomatyczna kierowana z Rzeczypospolitej do Rosji była pisana w języku polskim, a kierowaną z Rosji do Polski sporządzano w języku ruskim ${ }^{14}$.

Poseł udający się do innego państwa otrzymywał przygotowane przez kancelarię koronną dokumenty ${ }^{15}$, jednym z nich był list kredencjalny królewski, czyli list uwierzytelniający. Był on oficjalnym dokumentem informującym o celach misji. Bardzo ważne było dokładne określenie w nim tytulatury adresata. Na tym tle często dochodziło do sporów między dyplomatami polskimi a rosyjskimi. Kolejnym dokumentem była plenipotencja królewska precyzująca uprawnienia posła, $w$ tym dokładnie określająca granice, w jakich może podejmować decyzje. Był to dokument jawny. Jeżeli zakres przyznanych uprawnień był zbyt mały albo nie odpowiadał potrzebom, posłowie musieli wystąpić o nowe pełnomocnictwa. Osobno wydawano dyplomacie list kredencjalny od senatu i plenipotencję od senatu, a wreszcie instrukcję poselską. Był to najważniejszy, tajny dokument opracowywany w kancelarii koronnej lub litewskiej, który określał sposób osiągnięcia celu poselstwa i zasady zachowania posła. Podkreślał on znaczenie dbałości o godność króla i Rzeczypospolitej,

${ }^{10}$ BCzart., sygn. TN 169, rkps 39, s. 184, Poczta jedenasta, a z Stolice dziewiąta do Króla Jmci, 11 luty 1672.

11 Z. Wóscik: Rzeczpospolita wobec Turcji i Rosji 1674-1679. Wrocław 1976, s. 149.

12 Z. Wóıcıк: Dyplomacja polska w okresie wojen drugiej połowy XVII w. (1648-1699). W: Historia dyplomacji polskiej. T. 2: 1572-1795. Red. Z. Wójcıк. Warszawa 1982, s. 262-263.

${ }_{13}$ Z. WójCıк: Polska służba dyplomatyczna XVI-XVIII wieku. Warszawa 1966, s. 310-311.

${ }_{14}$ Z. Wóıсıк: Dyplomacja polska w okresie wojen..., s. 285.

15 Z. Wóıcıк: Polska służba dyplomatyczna..., s. 313-314. 
a czasami zawierał tekst przemówień dyplomaty ${ }^{16}$. W instrukcji wyznaczano zakres ustępstw, jakie posłowie mogli poczynić, a także regulowano sposób ich zachowania, szczególnie precyzyjnie wskazując sytuacje, kiedy powinni zdejmować czapki podczas uroczystości, a kiedy nie powinni tego robić. Podkreślana była konieczność podania pisma kredencjalnego do rąk własnych cara, a nawet takie szczegóły, jak konieczność powstania cara podczas pytania o zdrowie króla. Określano też sposób całowania carskiej ręki oraz zachowania podczas uczt w obecności cara. Układający instrukcję poselską rozpatrywali również zachowanie w czasie sporów o królewskie i carskie tytuły na pieczęciach urzędowych ${ }^{17}$.

Po zgromadzeniu niezbędnych dokumentów oraz pieniędzy ze skarbu państwa dyplomaci mogli wyruszyć z misją. Poselstwa udające się do Rosji z reguły były duże i pełne przepychu. Wynikało to $\mathrm{z}$ faktu, że w Rosji charakter poselstwa świadczył o wielkości i potędze państwa, z którego ono pochodziło. Duże znaczenie przywiązywano do prezentów, jakie planowano ofiarować carowi. Na przykład w 1667 roku aby wykazać dobrą wolę, polskie poselstwo zwróciło obraz Bogarodzicy zabrany w czasie wojny z rosyjskiej cerkwi. O znaczeniu tego gestu świadczy fakt, że umieszczono obraz w monastyrze Przenajświętszej Bogarodzicy, a następnie udał się do niego car Aleksy ${ }^{18}$.

$\mathrm{Na}$ granicy poselstwo było uroczyście witane przez przystawa ${ }^{19}$. Był on przysyłany przez wojewodę nadgranicznego miasta. Zgodnie z prawem panującym w Rosji żaden urzędnik nie mógł spotkać się z posłami przed ich odbyciem audiencji u cara. Dlatego też wojewoda mógł kontaktować się tylko z członkami poselstwa. Przystaw w czasie podróży do Moskwy miał zapewnić poselstwu „korm”, czyli wyżywienie oraz noclegi ${ }^{20}$. Wojewodowie na bieżąco informowali znajdujący się w Moskwie prikaz poselski, który odpowiadał za sprawy zagraniczne, o przebiegu podróży poselstwa.

Sposób zorganizowania podróży do Moskwy był wyrazem stosunków panujących pomiędzy obydwoma krajami. Na przykład w 1671 roku, aby powstrzymać przyjazd poselstwa do Moskwy i zmusić posłów do prowadzenia rozmów na granicy, na polecenie wojewody Iwana Chowańskiego „kazano napisy pomazać i kratami mosty pozastawiać” ${ }^{21}$, a drogi — „kobylibami”22. Nie przysłano przystawa oraz

16 Ibidem, s. 318.

17 Pamiętniki historyczne. T. 1. Wyd. L. Hubert. Warszawa 1861, s. 96-104.

18 Z. Wójcıк: Między traktatem andruszowskim a wojną turecką. Stosunki polsko-rosyjskie 1667-1672. Warszawa 1968, s. 84.

19 Przystaw to pomocnik, osoba asystująca. Zob. Słownik staropolski. T. 7. Wrocław 1973-1977, S. 362 .

20 S.W. Bachruszyn, S.D. Skazkin: Dyplomacja państw europejskich..., s. 314.

${ }^{21}$ F. Kluczycki: Pisma do wieku i spraw Jana Sobieskiego. T. 1. Kraków 1880, s. 741.

22 „Kobylica, kobylina, barjera, drzewo pełne kołów ostrych lub gałęzi, którem zakładano bramy i drogi dla przeszkodzenia wjazdu”. Z. GLOGER: Encyklopedja staropolska. T. 2. Warszawa 1902. 
zakazano sprzedaży żywności członkom poselstwa. Mimo to przedstawiciele polscy kontynuowali swoją misję i dotarli do celu ${ }^{23}$. Również poselstwo w 1657 roku było źle traktowane i stawiano stronie rosyjskiej zarzuty, że zajmują się nim urzędnicy niskiej rangi, co ubliżało godności posłów ${ }^{24}$. Generalnie przejazd poselstw przez Rosję był dobrze zorganizowany. Największe zastrzeżenia dotyczyły złego stanu dróg, mostów oraz braku czystości w miejscach kwaterowania ${ }^{25}$.

Po przybyciu w pobliże Moskwy poselstwo czekało na zgodę na wjazd do miasta. Dokonywał się on przeważnie przez Bramę Twerskąa ${ }^{26}$ W dniu wjazdu przysyłano z carskiej stajni powozy, karety, sanie, w których posłowie z towarzyszącym im orszakiem mieli udać się na audiencję. Ponadto dotychczasowych przystawów wymieniano na nowych. Ich zadaniem było dbać o przydzielone im osoby, zapewniać kontakty z prikazem poselskim oraz szpiegować członków poselstwa. Często spotkanie z przystawami prowadziło do sporów protokolarnych związanych z tym, kto pierwszy zdejmie w czasie powitania nakrycie głowy, czy jakie miejsce zajmie w karecie ${ }^{27}$. Najważniejszym jednak zadaniem przystawów oraz mieszkańców Moskwy - przynajmniej z punktu widzenia rosyjskiego — było dbanie o to, aby pokazać potęgę i bogactwo cara.

W 1661 roku tak opisano w liście uroczysty wjazd polskiego poselstwa do Moskwy: „Potkały nas w półtory mili od stolice konne i piesze wojska Cara Jmć: [...] Jazdy chorągwi mogło być 64, pieszych zaś $1433^{\prime 28}$. Aby uhonorować posłów, na potrzeby wjazdu do Moskwy car przekazał im swoją karetę ${ }^{29}$. Wjazd był okazją do pokazania bogactwa państwa rosyjskiego. W 1680 roku tak opisywano żołnierzy stojących wzdłuż trasy przejazdu, którzy zrobili największe wrażenie swoim wyglądem: „Najznamienitsi jednak byli carscy, alias nadworni żołnierze, którzy na kształt husarza naszego [...] szabli i ze skrzydłami konie osiodłali białe, drzewca

${ }^{23}$ F. Kluczycki: Pisma do wieku..., s. 739-743.

${ }_{24}$ Medeksza S. F. z Prószcza: Księga pamiętnicza wydarzeń zaszłych na Litwie 1654-1668. Kraków 1875, s. 37.

25 B. TAnner: Poselstwo polsko-litewskie do Moskwy w roku 1678 szczęśliwie przedsięwzięte, opisane przez naocznego świadka Bernarda Tannera (Norymberga 1689). Oprac. i wstęp A. STRojny. Kraków 2002, s. 146-152.

${ }^{26}$ Z. WójcıK: Dyplomacja polska w okresie wojen..., s. 295.

${ }^{27} \mathrm{~W} 1635$ roku doszło do trwających dwie godziny sporów pomiędzy polskimi posłami a Rosjanami o kolejność wysiadania $\mathrm{z}$ karety i zsiadania z koni. Poselstwo Aleksandra Piaseczyńskiego i Kazimierza Leona Sapiehy do Moskwy w 1635 roku. Oprac. A. Filipczak-Kocur. Opole 2017, s. $47-49$.

28 A. Grabowski: Ojczyste spominki w pismach do dziejów dawnej Polski, Diaryusze, Relacye, Pamiętniki i t.p. służyć mogące do objaśnienia dziejów krajowych: tudzież listy historyczne do panowania królów Jana Kazimierza i Michała Korybuta Wiśniowieckiego oraz listy Jana Sobieskiego marszałka i hetmana wielkiego koronnego z rękopisów zebrane przez Ambrożego Grabowskiego. T. 2. Kraków 1845, s. 151.

${ }^{29}$ Ibidem, s. 152. 
nie większe nad dzidy nasze mając" ${ }^{30}$. Car pragnąc olśnić poselstwo, nakazywał, aby przy trasie przejazdu gromadziły się jak największe tłumy ludności. Przykładowo w 1667 roku „wszytkich prawie bojarów i kupców w stolicy i przyległych miast do tey stryczy ruszono"31.

W 1667 roku przybyło do Moskwy poselstwo Kazimierza Bieniewskiego. Tak zostało opisane przywitanie poselstwa:

o milę od miasta spotkało ich wojska moskiewskiego w polu bardzo równem i przestronnem jak się zdawało, więcej niż dwadzieścia tysięcy ludzi, jazdy trzy części większe a czwarta piechoty trybem cudzoziemskim, której było regimentów pięć, każdy regiment w barwie innego koloru dobrze odziany, w obuwiu żółtem świeżem [...] Bojarowie, żołnierze i wszystka jazda w różne rynsztunki wojenne porządnie i dosyć strojno przybrana, bo wszystkich prawie bojarów i kupców z stolicy i przyległych miast do tej stryczy ruszono ${ }^{32}$.

Aby pokazać dobrą wolę, gospodarze nie przywiązywali wagi do zasad pierwszeństwa przy zajmowaniu miejsca w karecie. „Do powitania kto miał wprzód wysiąść żadnej controversci o pierwszeństwo nie było; spólnie opuścili ten niepotrzebny obyczaj" ${ }^{33}$.

Nie zawsze atmosfera wjazdu była tak sielankowa. W 1678 roku początkowo wjazd poselstwa do Moskwy przebiegał spokojnie. Potem doszło do „całkiem poważnego sporu między dworzanami posłów a wielkiego księcia o to, kto ma zająć zaszczytniejsze miejsce w powozach i w pochodzie. Tarcia trwały trzy godziny" ${ }^{34}$. Dopiero interwencja cara zakończyła ten spór: „Car zaś postanowił, żeby dwaj moskiewscy dworzanie wzięli pomiędzy siebie jednego Polaka, a w następnym szeregu dwaj Polacy jednego Moskowitę, i żeby tego porządku trzymali się w kolejnych szeregach" ${ }^{\prime 3}$.

Wjazd obserwowały tłumy mieszkańców zgromadzonych przy trasie przejazdu. Wzdłuż ulic stały szeregi żołnierzy. Wszyscy byli odświętnie ubrani. Ich obecność miała świadczyć o potędze i bogactwie Rosji oraz szacunku dla posłów. Rosjanie bardzo prestiżowo traktowali obecność tłumów na ulicach podczas przejazdu po-

\footnotetext{
${ }^{30}$ APT, sygn. Kat II, XIV-39, k. 37v, Ze Stolice Moskiewskiey de data 3 tia 7brys anno 1680.

${ }^{31}$ BCzart., sygn. TN 162, rkps 184, s. 880, Relacya przyięcia w Stolicy Moskiewskiey Panów Posłów Wielkich Jej; K: Mci; i Rzeczypospolitey, 27 X 1667.

32 Pamiętniki historyczne..., s. 76.

${ }^{33}$ Ibidem, s. 75-76.

${ }^{34}$ B. TANner: Poselstwo polsko-litewskie..., s. 166.

${ }^{35}$ Ibidem, s. 166; S.W. Bachruszyn, S.D. Skazkin: Dyplomacja państw europejskich..., s. 315 .
} 
słów. Poseł rosyjski Puszkin jadąc na audiencję u króla Francji, poczuł się obrażony z powodu zbyt małych, jego zdaniem, tłumów na trasie przejazdu ${ }^{36}$.

Następnie posłowie zostali umieszczeni w przyznanych im kwaterach. Miejsce zamieszkania zależało od rangi poselstwa. W XVI wieku polskich posłów kwaterowano $\mathrm{w}$ domach zajezdnych, a poselstwa innych państw w domach prywatnych. $\mathrm{Na}$ początku XVII wieku zbudowano dla posłów w Kitajgorodzie na Iljince specjalny pałac poselski - Posolskij dworiec. Celem była ochrona posłów oraz ich izolacja od mieszkańców Moskwy. Dom był otoczony strażą, która nie pozwalała posłom opuszczać tego terenu, a czasami wywierała zbrojną presję na członków poselstwa $^{37}$. Po audiencji u cara posłowie mogli wychodzić do miasta. Według przekazów rosyjskich od XVII wieku utrudnienia w kontaktach z miejscową ludnością były łagodzone wobec dyplomatów państw nieuznawanych za wrogie ${ }^{38}$.

Uczestnik poselstwa do Moskwy w 1678 roku, Bernard Tanner, przedstawił opis pałacu poselskiego zbudowanego przez cara Aleksego Michajłowicza. Był to ceglany trzypiętrowy budynek, wzniesiony na planie kwadratu. Posiadał części przeznaczone dla posłów, członków poselstwa, kuchnie i stajnie. Ściany były obite tkaninami. Uwagę B. Tannera zwróciły okna:

wszystkie okna w większym stopniu były żelazne i kamienne niż szklane i przejrzyste, zaś w tych które wychodziły na ulicę, tkwiły głęboko wpuszczone w ścianę kraty o grubości odpowiadającej ludzkiej pięści. [...] przed poszczególnymi oknami Moskwicini rozstawili jeszcze pewną liczbę uzbrojonych strażników, dla ochrony, jak mówili przed zakusami rozbójników i złodziei ${ }^{39}$.

Członkowie poselstwa z 1671 roku narzekali na tłok panujący w pałacu poselskim oraz na zbyt małe fundusze, jakie gospodarze przeznaczali na ich utrzymanie. Powody złego traktowania widziano w intencjach gospodarzy: „znać że oni mają na sercu cokolwiek skrytego, kiedy nam non in antiquaforma humanitatis et provisionis officia praesta" oraz w chęci odwetu za zke traktowanie poselstwa rosyjskiego w Warszawie ${ }^{40}$. Czasami Rosjanie utrudniali utrzymywanie korespondencji z Rze-

${ }^{36}$ S.W. BaChruszyn, S.D. SKazkin: Dyplomacja państw europejskich..., s. 316.

37 A. Grabowski: Ojczyste spominki..., t. 1, s. 47.

${ }^{38}$ Historia dyplomacji do 1871 r. T. 1..., s. 316. W 1644 roku Rosjanie próbowali wpływać na polskie poselstwo, ograniczając swobodę poruszania się oraz racje żywnościowe dla jego członków. T. KемPA: „Samozwaniec” Jan Faustyn Łuba - ofiara dyplomatycznych sporów między Rzeczpospolita a Moskwa w latach 40. XVII w. W: Studia z dziejów Wielkiego Księstwa Litewskiego (XVI-XVII wieku). Red. S. Górzyński, M. NAGIELSKi. Warszawa 2014, s. 227.

39 B. TANner: Poselstwo polsko-litewskie..., s. 169-171.

40 A. Grabowski: Ojczyste spominki..., t. 2, s. 152. Skargi na złe zakwaterowanie i zbyt małą ilość dostarczanego jedzenia zdarzały się wcześniej, np. w czasie poselstwa w 1635 roku. Poselstwo Aleksandra Piaseczyńskiego..., s. 50. 
cząpospolitą. W 1679 roku polskich gońców „Panowie Moskiewscy przepuścić nie chcieli, a nawet do stolicy nam nie dali znać” o ich przybyciu. Aby przeczytać list w spokoju, posłowie „o mil kilka jechać musieli”"

Uroczysty przejazd do pałacu na audiencję odbywał się w przysłanych przez cara karetach i na przysłanych koniach. W drodze towarzyszyli poselstwu odświętnie ubrani przystawowie. Przed posłami jechał sekretarz poselstwa, trzymając listy uwierzytelniające zawinięte $\mathrm{w}$ jedwabną tkaninę - kamchę $e^{42}$. Jak wspomniano, spory o pierwszeństwo, kto pierwszy się ukłoni, zdejmie czapkę czy będzie punktualny oraz o miejsce, gdzie zsiądzie $\mathrm{z}$ konia, zdarzały się wielokrotnie ${ }^{43}$. W pałacu posłów witali odświętnie odziani bojarzy, urzędnicy prikazów i kupcy. Byli oni ubrani w złociste stroje oraz wysokie czapki wypożyczone im na czas uroczystości. Po jej zakończeniu musieli je zwrócić do carskich magazynów. Za uszkodzenie albo zabrudzenie stroju groziły surowe kary ${ }^{44}$.

Ranga przyjmowanego poselstwa decydowała o tym, ilu bojarów je witało. Przyjęcie odbywało się zazwyczaj w sali Stołowej, w jednej ze Złotych albo w sali Granowitej. Car udzielał audiencji, siedząc na tronie w „wielkim stroju”. Składał się on z szaty ze złotogłowiu i Czapki Monomacha ${ }^{45}$. W jednym ręku władca trzymał berło, a w drugim jabłko carskie. Przed tronem stali uzbrojeni w srebrne siekiery i ubrani na biało „ryndowie”46. Pod ścianami na ławach siedzieli bojarzy. Czasami towarzyszyli carowi następca tronu oraz inni książęta.

W polskich instrukcjach poselskich przykładano wielkie znaczenie do zachowania posłów, którzy mieli wchodzić do sali audiencyjnej w czapkach na głowie. Powodowało to stałe konflikty z Rosjanami, którzy od drugiej połowy XVII wieku żądali od posłów, aby wchodząc na salę audiencyjną, ściągali czapki. Spory powsta-

${ }^{41}$ BCzart., sygn. TN 177, rkps 249, s. 1165, Kopia listu do Jana III Króla od Cypriana Brzostowskiego W. Posła w Moskwie, 7 X 1679.

${ }_{42}$ Kamcha (z persk. kamcha, podobno chińskiego pochodzenia) - rodzaj atłasu jedwabnego, drogiego, wyrabianego na wschodzie. Z. GLOGER: Encyklopedja staropolska. T. 2...

${ }^{43}$ S.W. Bachruszyn, S.D. Skazkin: Dyplomacja państw europejskich..., s. 314.

${ }^{44}$ Ibidem, s. 316.

${ }_{45}$ Ibidem, s. 317. Czapka Monomacha to korona carska wykorzystana po raz pierwszy w 1498 roku. K. Chojnicka: Narodziny rosyjskiej doktryny państwowej. Kraków 2008, s. 86.

${ }^{46}$ Ryndowie - straż przyboczna cara. Tak ją opisał w czasach Borysa Godunowa rosyjski historyk Nikołaj Michajłowicz Karamzin: „ryndowie w białym ubiorze aksamitnym lub atłasowym wykładanym gronostajami, w wysokich białych czapkach, $\mathrm{z}$ dwoma złotemi łańcuchami (założonemi na krzyż na piersiach), z kosztownemi toporami, podniesionemi na plecy jakby dla zadania razu". N.M. Kara mzin: Historia państwa rosyjskiego. T. 10. Warszawa 1827. B. Tanner w swojej relacji zauważył, że było ich „czterech znaczniejszych urzędników”. B. TANner: Poselstwo polsko-litewskie..., s. 174. E. Pielgrzymowski w swojej relacji z poselstwa do Rosji w latach 1600/1601 przyrównał ich do starożytnych liktorów. E. Pielgrzy Mowski: Poselstwo i krótkie spisanie rozprawy z Moskwa. Wyd. i oprac. R. KRzYwy. Warszawa 2010, s. 54. W relacji z poselstwa w 1635 roku określono ich jako custodes corporis. Zob. Poselstwo Aleksandra Piaseczyńskiego..., s. 50. 
jące na tym tle starano się rozwiązywać polubownie. Posłowie oraz członkowie poselstwa udając się na audiencję, musieli zostawić broń w domu albo przekazać ją straży pałacowej ${ }^{47}$.

Przebieg audiencji w 1667 roku był następujący. Wchodząc do sali audiencyjnej, posłowie odmówili zdjęcia nakryć głowy. Spowodowało to, że „przyszło się umawiać posłom w samych drzwiach, i stąd się wzięła ta kontrowersya kilka pacierzy, aż zdanim samego Cara JMości uspokojona" ${ }^{48}$. W opisie przebiegu poselstwa nie podano, na czym miała polegać carska interwencja. Zgodnie z polskimi relacjami posłowie dopiero przed obliczem cara oraz siedzącego przy nim syna stanęli z odkrytymi głowami. Z kolei w rosyjskiej relacji odnotowano, że posłowie zdjęli nakrycia głowy, już przekraczając drzwi sali tronowej ${ }^{49}$. Przybyłych posłów przedstawił diak poselski i zezwolił im na przemówienie do cara. Pierwszy poseł „witał JM. Cara imieniem króla JMci, życząc zdrowia i fortunnego panowania, oraz i carewicza słowami ułożonemi. Po przemowie JP wojewody, car Jego Mość powstawszy i sprawiedliwie stojąc, wyraźnemi słowy pytał o zdrowie Jego Królewskiej Mości”50. Car zadał to pytanie, mając koronę na głowie. Natomiast carewicz pytał o zdrowie króla z odkrytą głową. Odpowiedzi udzielał kierujący poselstwem. Następnie pierwszy poseł wygłosił przemówienie oraz oddał list kredencjalny królewski. Kolejnym punktem były krótkie przemówienia drugiego posła oraz sekretarza poselstwa ${ }^{51}$.

Po wręczeniu listów uwierzytelniających ${ }^{52}$ oraz przemówieniach posłów car dawał dłoń do ucałowania. Podczas tej legacji całowano również dłoń jego syna.

47 B. TAnner: Poselstwo polsko-litewskie..., s. 172.

${ }^{48}$ Pamiętniki historyczne..., s. 78.

${ }^{49}$ Z. WójCıк: Między traktatem..., s. 87. W relacji z tego poselstwa znajdującej się w Bibliotece Książąt Czartoryskich napisano wprost, że posłowie nie zdjęli czapek. BCzart., sygn. TN 162, rkps 184, s. 883, Relacya przyięcia w Stolicy Moskiewskiey Panów Posłów Wielkich Jei; K: Mci; i Rzeczypospolitey, 28 X 1667. Por. BCzart., sygn. TN 177, rkps 314, s. 1383, Relacya Poselstwa od króla Jmci Jana III y od Rzeczypospolitey z Seymu grodzieńskiego ordynowanego, przez nas Cypriana Pawła Brzostowskiego Referendarza W. Księstwa Litewskiego, Oszmiańskiego Starostę, iako Posła wielkiego, y Jana Gnińskiego starostę Radzyńskiego, jako sekretarza tegoż Poselstwa w roku 1679 odprawionym. W relacji z tego poselstwa zapisano, że obie strony starały się unikać sporów związanych ze zdejmowaniem nakryć głowy w obecności cara. Postanowiono, że w oparciu o „przeszłe postanowienia o czapkach uczynione, że kontrowersyi żadnej o nią czynić nie będziemy”.

${ }^{50}$ Pamiętniki historyczne..., s. 78. Z obowiązku wstawania monarchy, kiedy pytał o zdrowie cara, albo kiedy car pytał o zdrowie króla, nie zwalniała nawet choroba. Wówczas dworzanie powinni pomóc powstać królowi albo carowi. A. DARowski: Szkice historyczne, seria trzecia. Petersburg 1897, s. 273-274.

${ }^{51}$ Historia dyplomacji polskiej. T. 2..., s. 296.

${ }^{52}$ Zgodnie z ceremoniałem rosyjskim car przyjmował listy uwierzytelniające osobiście. Tylko w wyjątkowych przypadkach, np. z obawy przed zarazą, ta zasada nie była dotrzymywana. Stało się tak w 1657 roku, kiedy polscy połowie przejeżdżali przez tereny, na których panowała epidemia. Medeksza S.F. z Prószcza: Księga pamiętnicza..., s. 120. 
Carską dłoń można było pocałować, ale nie dotykać swoimi dłońmi. Mogli ją całować tylko chrześcijanie. Muzułmanom car kładł rękę na głowie ${ }^{53}$. Dawniej po tej ceremonii car obmywał dłoń w srebrnym naczyniu stojącym u stóp tronu. Ten zwyczaj szczególnie oburzał posłó ${ }^{54}$. W relacjach z drugiej połowy XVII wieku brak już o nim wzmianki.

Po ucałowaniu carskiej dłoni posłowie siadali naprzeciwko tronu na przyniesionej ławie albo na przyniesionych zydlach. „Gdy posłowie usiedli oraz i czapki na głowę włożyli, zaraz dyak expostulować począł, że miasto cześci bezcześć czynicie Carowi”"55. Posłowie bronili się, że w swojej osobie „godność Pana swego i Rzeczypospolitej zatrzymują"56 i dlatego muszą mieć nakryte głowy. Rosjanie natomiast utrzymywali, że w Polsce posłom carskim nie pozwala się ubierać czapek w takiej samej sytuacji ${ }^{57}$. Ostatecznie pozwalano posłom zachować czapki na głowach.

Następnym punktem audiencji było rozdanie upominków przywiezionych przez posłów oraz członków poselstwa: „naprzód od Króla JM, potem od posłów, nareszcie i od dworzan królewskich, według regestru od samego diaka czytanego" ${ }^{18}$. Na zakończenie audiencji car za pośrednictwem mistrza ceremonii pytał o zdrowie posłów ${ }^{59}$.

W dniu audiencji była przewidziana uczta, którą car urządzał dla członków poselstwa. Przed XVII wiekiem posłowie ucztowali w obecności cara. Potem upowszechnił się zwyczaj, że posłom posyłano poczęstunek do pałacu poselskiego ${ }^{60}$. Instrukcje przygotowywane przez stronę polską dla dyplomatów udających się do Rosji przewidywały również sytuację, że car mógł się wymówić od spożycia obiadu z posłami z powodu choroby ${ }^{61}$.

Bernard Tanner przedstawił opis posiłku przekazanego z carskiej kuchni. Mimo starań o jak najbardziej okazałe ugoszczenie poselstwa nie uniknięto nieporozumień. Przede wszystkim przedstawiciel cara „nakrył obrusem początek stołu, którą to część przeznaczono dla posłów, i ustawił na nim w odpowiednim porządku sześć

53 S.W. Bachruszyn, S.D. Skazkin: Dyplomacja państw europejskich..., s. 317.

54 O tym obyczaju pisał Stanisław Niemojewski, uważając, że car obmywając ręce, „nie chce być niczem zmazanym tą mową, którą słyszał od cudzoziemca”. S. Niemojewski: Pamiętnik Stanisława Niemojewskiego (1606-1608). Wyd. A. Hirschberg. Lwów 1899, s. 30 (nowsze wydanie: S. Niemojewski: Diariusz drogi spisanej i różnych przypadków pociesznych i żałosnych prowadząc córkę Jerzego Mniszka, Marynę, Dymitrowi Iwanowiczowi w roku 1606. Wyd. R. KRzYwy. Warszawa 2006). Antonio Possevino uważał, że ten zwyczaj wypływał z niechęci do katolicyzmu. A. Possevino: Moscovia. Tłum. ks. A. WARкотsch. Warszawa 1988, s. 11.

55 Pamiętniki historyczne..., s. 79.

56 Ibidem.

57 Ibidem.

58 Ibidem.

59 Z. Wójcıк: Dyplomacja polska w okresie wojen..., s. 296.

60 S.W. Bachruszyn, S.D. Skazkin: Dyplomacja państw europejskich..., s. 318.

${ }^{61}$ Pamiętniki historyczne..., s. 100. 
srebrnych talerzy oraz łyżki i noże. Reszta stołu pozostała nienakryta"62. Dopiero po interwencji posłów nakryto obrusami pozostałe stoły. Liczba potraw sięgała dwustu, ale z powodu odmiennych gustów kulinarnych nie smakowały one członkom poselstwa ${ }^{63}$. Podobne nieporozumienia $\mathrm{z}$ zastawą, którą przynoszono tylko dla posłów, miały inne poselstwa. W czasie uczty zorganizowanej dla poselstwa holenderskiego podano nakrycia tylko posłom, a pozostali jego członkowie korzystali z własnych talerzy. Ważnym elementem uczty były toasty wznoszone na cześć cara ${ }^{64}$.

Po pierwszej następowała druga audiencja. Nie była ona tak uroczysta i miała charakter roboczy. W imieniu cara przemawiał diak, informując posłów o przyjęciu przez cara gramoty królewskiej. Następnie przedstawiał posłom bojarów, którzy zostali wyznaczeni do prowadzenia rokowań ${ }^{65}$.

Często poselstwa udawały się do Moskwy, aby car zaprzysiągł zawarte układy. Ceremonia zaprzysiężenia przez cara rozejmu zawartego w Andruszowie w 1667 roku przebiegła następująco:

Kazano potem przynieść zydel i siedzieć JMPanom posłom; skoro usiedli pytano o zdrowie Króla także i dworzan królewskich. Potym brał się Car JMci do przysięgi. Naprzód berło jednemu z bojarów dumnych, potem koronę z głowy zdjąwszy drugiemu oddał. Postawiony przed niego pulpit z księgą, w której zawierają się Ewangelie święte [...]. Powstawszy Car JMci a JMPP. posłów bliżej siebie wezwawszy, hramotę potwierdzalną pod Ewangelię włożywszy, czynił przysięgę wedle ułożonej roty na pamięć głośno. Gdy przyszło do słów tych: wzywaju na świadectwo Boha w Trojcy Jedynaho, Jezusa Chrystusa i Preczistoju Bohorodicu, zapłaknąwszy przy ostatnich słowach, wykonał przysięgę nabożnie i doskonale ${ }^{66}$.

Po złożeniu przysiegi car całował krzyż, a tekst układu przekazywał posłom. Car nie podpisywał tekstu układu, podpis składał dumski diak ${ }^{67}$. Następnie poseł wygłosił przemowę wyrażającą radość z zawartego układu. Na zakończenie car zaprosił posłów na obiad. Przyjazną atmosferę obiadu podkreślał fakt, że car i posłowie siedzieli bez nakryć głowy.

Po zakończeniu rokowań odbywała się pożegnalna audiencja. Sposób pożegnania posłów zależał od wyniku rokowań. Jeżeli ich rezultat był pomyślny dla cara, to posłów częstowano miodem podanym w czarach. Podczas uczty car zapraszał

62 B. TAnner: Poselstwo polsko-litewskie..., s. 177.

63 Ibidem, s. 176-179.

64 S.W. Bachruszyn, S.D. Skazkin: Dyplomacja państw europejskich..., s. 318.

65 Z. Wóıcıк: Dyplomacja polska w okresie wojen..., s. 296.

66 Pamiętniki historyczne..., s. 89.

67 S.W. BaChruszyn, S.D. Skazkin: Dyplomacja państw europejskich..., s. 319. 
posłów do siebie i jedną czarą wznosił toast za zdrowie króla, a drugą podawał posłowi ${ }^{68}$. Posłowie po wypiciu miodu często zabierali czary z sobą, $\mathrm{z}$ tego powodu, w Anglii zamawiano „specjalne miedziane czarki, posrebrzane i pozłacane" 69 .

Podczas uczty pożegnalnej car siedział na niskim tronie. Życzył posłom kończącym swoją misję szczęśliwej podróży i dawał im podarunki. W dowód łaskawości pozwalał ucałować swoją dłoń. Audiencja kończyła się życzeniami, jakie car składał władcy kraju, z którego pochodzili posłowie. Po uczcie posłom wysyłano pożegnalny poczęstunek z carskiej kuchni, który mieli zjeść w miejscu zakwaterowania ${ }^{70}$.

Pod koniec misji car obdarowywał posłów prezentami w rewanżu za otrzymane dary. Niestety przeważnie obdarowani nie byli z nich zadowoleni. Zdarzało się tak wielokrotnie, np. w 1570 roku polski poseł "miotał podarki mu posłane" ${ }^{\text {"11 }}$. Niezadowolenie z prezentów okazano również w czasie poselstwa Lwa Sapiehy w 1601 ro$\mathrm{ku}^{72}$ oraz Michała Czartoryskiego i Kazimierza Jana Sapiehy w 1678 roku, kiedy wiele osób odmówiło przyjęcia darów z powodu, ich zdaniem, zbyt małej wartości, a nawet zażądało zwrotu swoich darów ofiarowanych w czasie audiencji ${ }^{73}$.

Po zakończeniu misji dyplomaci musieli niezwłocznie opuścić pałac poselski. Poselstwo polskie w 1667 roku poganiane przez przystawów musiało się spakować w ciągu dwóch godzin ${ }^{74}$. Również w 1620 roku poselstwu nakazano w ciągu jednej nocy spakować się i opuścić Moskwę. Mimo panujących mrozów nie pozwolono zakupić dla czeladzi kożuchów ani butów ${ }^{75}$.

W polskiej dyplomacji XVII wieku ważną rolę odgrywali „posłowie i komisarze króla i Rzeczypospolitej”76. Nie prowadzili oni rozmów w stolicach państw ościennych, ale w terenie niezabudowanym w namiotach. Często spotkania odbywały się w miejscowościach nadgranicznych albo położonych w pobliżu przyszłej granicy. Rozmowy takie, zwane komisjami, odbywały się na przykład w 1656 roku w Niemieży, w latach 1666-1667 w Andruszowie, w 1676 roku w Żurawnie. Praca tej grupy posłów służyła prowadzeniu długotrwałych rokowań mających na celu zawarcie rozejmu, pokoju ${ }^{77}$. Uczestniczący w nich dyplomaci nie mieli tej samej rangi co wielcy posłowie, oprawa rozmów nie była tak uroczysta, ale mimo to sprawy związane z etykietą i ceremoniałem odgrywały ważną rolę ${ }^{78}$.

${ }^{68}$ Z. WóıCıк: Dyplomacja polska w okresie wojen..., s. 296.

${ }^{69}$ S.W. Bachruszyn, S.D. Skazkin: Dyplomacja państw europejskich..., s. 318.

70 B. TAnner: Poselstwo polsko-litewskie..., s. 221.

${ }^{71}$ Ł. Górnicki: Dzieje w Koronie Polskiej. Oprac. H. BARYCz. Wrocław 2003, s. 168.

72 E. Pielgrzy mowski: Poselstwo i krótkie spisanie rozprawy..., s. 209.

73 B. Tanner: Poselstwo polsko-litewskie..., s. 225.

${ }^{74}$ Ibidem, s. 238.

75 A. Grabowski: Ojczyste spominki..., s. 52.

${ }^{76}$ Z. Wóјсıк: Dyplomacja polska w okresie wojen..., s. 264.

77 Ibidem, s. 264-265.

${ }^{78}$ S.W. BAChruszyn, S.D. Skazkin: Dyplomacja państw europejskich..., s. 318. 
Pierwszym etapem powołania komisji było ustalenie jej składu oraz wyposażenie jej w niezbędne dokumenty. Wśród nich była plenipotencja do prowadzenia rozmów z posłami moskiewskimi oraz instrukcja poselska. W instrukcji przedstawiano aktualną sytuację polityczną, cele prowadzenia rozmów oraz sposób ich osiągnięcia ${ }^{79}$. W rozmowach mogli uczestniczyć jako mediatorzy obcy dyplomaci. Tak było w czasie negocjacji z 1656 roku w Niemieży. Jako pośrednicy między stroną polską i rosyjską brali w nich udział austriaccy dyplomaci: don Alegretto Alegretti oraz Teodor von Lorbach ${ }^{80}$.

Rozmowy komisji prowadzone były w miejscach odległych od dużych miast, a w czasie wojny - w pobliżu granicy demarkacyjnej między państwami (jak w 1666 roku w Andruszowie). Miejsce obrad musiało być zaakceptowane przez obie strony. Przyjazd delegacji był często wykorzystywany przez Rosjan do wywarcia nacisku na polską komisję. Dokonywali tego przez przydzielanie swoim komisarzom znacznie większych oddziałów wojskowych, niż wymagały tego potrzeby ochrony. Na przykład w 1656 roku ich komisja miała asystę 7 tys. żołnierzy ${ }^{81}$. W 1664 roku poselstwo z Moskwy przybyło w asyście tysięcznej piechoty uzbrojonej w $18 \mathrm{dział}{ }^{82}$.

Ważnym zagadnieniem był sposób zorganizowania obrad. Poselstwa utrzymywały się ze swoich środków i same zaopatrywały się w żywność. Komisje mieszkały w wioskach położonych w pobliżu miejsca obrad, które prowadzono w namiotach rozbitych w szczerym polu. Na przykład w 1656 roku w Niemieży postawiono cztery namioty: dla Polaków, dla Rosjan, dla mediatorów i do prowadzenia obrad. W tym ostatnim postawiono stół, przy którym zasiadali dyplomaci ${ }^{83}$. Na potrzeby prowadzenia rozmów komisji w 1664 roku w Durowiczach postanowiono „blisko e contra postawić namioty et inter medio loco sub dio z sobą schodzić się i traktować" ". Polscy posłowie zażądali, aby zburzyć wcześniej zbudowaną szopę przez Rosjan, ponieważ uważali, że nie jest to odpowiednie miejsce dla prowadzenia obrad. Podczas rozmów każda $\mathrm{z}$ delegacji zajmowała miejsce przy swoim stole ${ }^{85}$.

W 1666 roku w trakcie rozmów w Andruszowie polscy komisarze wyrazili zgodę na obrady w wybudowanej przez Rosjan szopie, ale zażądali, aby jej ściany obito materiałem. Rosjanie podejrzewali, że to żądanie miało na celu opóźnienie rozpoczęcia rokowań ${ }^{86}$. Dlatego kierujący komisją rosyjską Afanasij Ławrientowicz Ordin Naszczokin tak skomentował to żądanie: „choćby ją złotogłowiem obili,

${ }^{79}$ L. Kubala: Wojna brandenburska i najazd Rakoczego 1656 i 1657. Lwów-Warszawa 1917, s. 32 .

${ }^{80}$ A. Darowski: Szkice historyczne, seria druga. Petersburg 1895, s. 353-354.

${ }^{81}$ L. Kubala: Wojna brandenburska..., s. 34.

82 J.A. Chrapowicki: Diariusz. Część pierwsza: lata 1656-1664. Oprac. T. WAsilewski. Warszawa 1978, s. 488.

83 A. DARowski: Szkice historyczne, seria druga..., s. 355.

${ }^{84}$ J.A. Chr a pow ICKi: Diariusz. Część pierwsza..., s. 490.

${ }^{85}$ Ibidem.

86 A. DARowsкi: Szkice historyczne, seria druga..., s. 428. 
kiedy w sercu nie będzie szczyrości, tedy to nic to nie waży"87. Kiedy nastały mrozy rokowania przeniesiono do kurnej chaty w Andruszowie ${ }^{88}$.

Podczas wstępnych negocjacji najważniejszą sprawą było pisemne i wzajemne zapewnienie bezpieczeństwa uczestnikom prac komisji oraz posłańcom przewożącym listy ${ }^{89}$. Czasami uzgodnienie treści pisma dotyczącego bezpieczeństwa wymagało długich rokowań. Drugą bardzo istotną kwestią było przekazanie właściwie wypełnionych pełnomocnictw do prowadzenia rozmów. Otrzymane dokumenty przekazywano tłumaczom. Ten etap nazywał się introdukcją komisji, odpowiedzialny za niego był najstarszy godnością uczestnik komisji. Pełnomocnictwa do prowadzenia rozmów były wnikliwie sprawdzane pod kątem formalnym, tj. prawidłowych pieczęci, podpisów oraz tego, kto ich udzielał. Często dochodziło do sporów o zastosowaną królewską albo carską tytulaturę. Ten problem rozwiązywano, stosując tytuły krótkie z pominięciem ich spornych fragmentów ${ }^{90}$.

Komisje obradowały w trakcie zjazdów. Czasami obrady trwały bardzo długo. Na przykład podczas komisji andruszowskiej pierwszy zjazd odbył się 10 maja $1666 \mathrm{roku}^{91}$, a ostatni - trzydziesty siódmy - 31 stycznia $1667 \mathrm{roku}^{92}$. Pomiędzy zjazdami komisarze kontaktowali się ze sobą za pomocą listów. Ponadto prowadzili ożywioną korespondencję z królem oraz innymi urzędnikami. Celem korespondencji było uzgodnienie sposobu negocjacji, otrzymanie dalszych instrukcji oraz przekazanie informacji o wydarzeniach w Rzeczypospolitej i w Europie, szczególnie tych, które mogły mieć znaczenie dla negocjacji. Ważna korespondencja do króla i senatorów była szyfrowana ${ }^{93}$. W celu omówienia szczególnie drażliwych kwestii oraz zachowania dyskrecji prowadzono rozmowy bez świadków, tj. semotis arbitris $^{94}$. Podczas rozmów Rosjanie próbowali naciskać na posłów, grożąc zerwaniem rozmów albo zakazując sprzedaży żywności ${ }^{95}$.

Po zakończeniu negocjacji i osiągnięciu porozumienia podpisywano tekst traktatu. Nie zawsze przebiegało to bezproblemowo. Na przykład w Niemieży (1656) doszło do sporów związanych z tytulaturą króla i cara. Ostatecznie traktat podpisano, a następnie komisarze polscy i rosyjscy wydali dwie uczty. Przed pożegnaniem wzajemnie obdarowali się prezentami ${ }^{96}$.

${ }^{87}$ J.A. Chrapowicki: Diariusz. Część druga: lata 1665-1669. Oprac. T. Wasilewski. Warszawa 1978, s. 125.

${ }^{88}$ A. Darowski: Szkice historyczne, seria druga..., s. 459.

${ }^{89}$ Ibidem, s. 404-405.

${ }^{90}$ Ibidem, s. 396-398; J.A. Chr a Pow Iскі: Diariusz. Część pierwsza..., s. 494-496.

${ }^{91}$ J.A. Chrapowicki: Diariusz. Część druga..., s. 127.

92 Ibidem, s. 278.

93 A. DA Rowski: Szkice historyczne, seria druga..., s. 405.

94 A. Chra powicki: Diariusz. Część pierwsza..., s. 502.

95 A. Chra powicki: Diariusz. Część druga..., s. 249.

${ }^{96}$ L. Kubala: Wojna brandenburska..., s. 60-61. 
Podpisanie i zaprzysiężenie traktatu w Andruszowie (1667) przebiegało następująco:

Szliśmy tedy do izby gdzie już byli Moskiewscy; tamże wprzód oni, potem myśmy podpisali. Niedługo bawiąc szliśmy do szopy, w której ten wszytek czas a die 1 maii traktowaliśmy. Tam był ołtarz moskiewski sporządzony obraz Chrystusa Pana, oni zowią Spasa, samego cara - cudowny, jako powiadali. Jakoż srodze piękny obraz — niewielki, ale cudownie przyjemny. Przysięgliśmy zatem comprobando pakta [...]. Po przysiędze subsecuta contestatio przez pierwszego kolegę, że dotrzymamy pokoju, wzajem i [Afanasij Ławrientowicz Ordin] Naszczokin toż deklarował"

W dalszej kolejności wymieniono podarunki. Jan Antoni Chrapowicki opisujący te wydarzenia nie wspomniał o wystawieniu uczty przez którąkolwiek ze stron. Można domniemywać, że nie uznał za potrzebne pisać o tym fakcie albo komisarze byli tak zmęczeni długotrwałymi negocjacjami, że pragnęli jak najszybciej udać się do domów.

Sprawy ceremoniału, zgodnie z którym odbywały się kontakty dyplomatyczne pomiędzy Rzecząpospolitą a Rosją, w XVII wieku były w dużym stopniu sformalizowane i powtarzalne. Dotyczyło to przede wszystkim kontaktów realizowanych w czasie misji wielkich posłów oraz długotrwałych rozmów prowadzonych podczas komisji przez „wielkich i pełnomocnych komisarzy”98. Mimo to dochodziło do nieporozumień. Najczęściej dotyczyły one spraw prestiżowych związanych z ochroną godności władców lub samych dyplomatów. Nieporozumienia starano się rozwiązywać polubownie. Rosjanie podczas rozmów próbowali pokazać wielkość, potęgę i bogactwo swojego państwa. Stosowali również naciski na dyplomatów poprzez lokowanie w pobliżu miejsca negocjacji dużych oddziałów wojskowych oraz pogarszanie warunków pobytu posłów w Moskwie. Poważny wpływ na rozmowy dyplomatów miał brak wzajemnego zaufania. Świadczy o tym opinia, jaką J.A. Chrapowicki podsumował swoją relację z podpisania rozejmu w Andruszowie: „Ale ja im nigdy, jako foedifragis nie wierzam i synom moim za testament to podaję, żeby pod błogosławieństwem rodzicielskim ode mnie to mieli, że temu narodowi nie trzeba ufać, bo i teraz oni jeno to czasowi wygadzali, a zawsze są nam głównymi nieprzyjacioły"99. Również w Moskwie nie darzono Polaków zaufaniem, czego przykładem jest pełna obaw reakcja Rosjan na zawarcie rozejmu w Żurawnie. Nie dowierzano nawet opublikowanemu tekstowi traktatu, podejrzewając, że zawiera

\footnotetext{
97 J.A. Chr a powicki: Diariusz. Część druga..., s. 277-278.

98 Z. Wóıсıк: Dyplomacja polska w okresie wojen..., s. 265.

99 Ibidem, s. 278.
} 
tajne klauzule ${ }^{100}$. Nad wzajemnym brakiem zaufania przeważała jednak obawa przed Turcją i ten czynnik wymuszał współpracę pomiędzy Rzecząpospolitą a Rosją.

\section{Bibliografia}

Bachruszyn S.W., SKazkin S.D.: Dyplomacja państw europejskich w XVII w. W: Historia dyplomacji do $1871 r$. T. 1. Red. W.M. Chwostowa et al. Warszawa 1973.

CHojNicKa K.: Narodziny rosyjskiej doktryny państwowej. Zoe Paleolog - między Bizancjum, Rzymem a Moskwą. Kraków 2001.

Darowski A.: Szkice historyczne, seria druga. Petersburg 1895.

Gloger Z.: Encyklopedja staropolska. T. 3. Warszawa 1902.

KемPA T.: „Samozwaniec” Jan Faustyn Łuba - ofiara dyplomatycznych sporów między Rzeczpospolita a Moskwa w latach 40. XVII w. W: Studia $z$ dziejów Wielkiego Księstwa Litewskiego (XVI-XVII wieku). Red. S. GórzyŃsKi, M. NAGIELSKI. Warszawa 2014.

Kubala L.: Wojna brandenburska i najazd Rakoczego 1656 i 1657. Lwów-Warszawa 1917.

Perdenia J.: Rokowania polsko-rosyjskie w Kadzyniu w 1684 r. „Rocznik Naukowo-Dydaktyczny” 1968, 22.

PietKiewicz E.: Protokół dyplomatyczny. Warszawa 1998.

Słownik staropolski. T. 7. Wrocław 1973-1977.

SuRMACZ B.: Ewolucja współczesnej dyplomacji: aktorzy, struktury, funkcje. Lublin 2015.

WójCıк Z.: Dyplomacja polska w okresie wojen drugiej połowy XVII w. (1648-1699). W: Historia dyplomacji polskiej. T. 2: 1572-1795. Red. Z. WójCıк. Warszawa 1982.

WójCıK Z.: Między traktatem andruszowskim a wojną turecką. Stosunki polsko-rosyjskie 1667-1672. Warszawa 1968.

WójCıк Z.: Polska służba dyplomatyczna XVI-XVIII wieku. Warszawa 1966.

Wójciк Z.: Rzeczpospolita wobec Turcji i Rosji 1674-1679. Wrocław 1976.

100 Z. Wóıсıк: Rzeczpospolita wobec Turcji i Rosji..., s. 83, 147.

Jerzy Wojciechowski

Opinions regarding diplomatic etiquette in Russia

based on the accounts of Polish envoys in the second half of the 17 th century

Summary

Diplomacy is one of the ways of carrying out foreign policy. It is implemented during negotiations of a given country's envoys with representatives of other countries. The manner of receiving envoys (foreign diplomats) and proceeding with negotiations is specified by diplomatic etiquette. The article describes how those relationships were effectuated in the second half of the 17th century between 
Poland and Russia. Diplomatic missions are described from the moment of receiving indispensable documents and plenipotentiary powers, through traveling to Moscow under supervision of the pristavs (Russian pristavy), to the conclusion of mission. The description of envoys' stay in Moscow includes details of accommodation, organizing audiences, feasts, entering into treaties, adherence to rules of appropriate behaviour in the tsar's presence and keeping proper forms of address. Also, a peculiar way of carrying out lengthy negotiations by king and country's envoys and commissaries is presented.

Key words: audience, diplomatic etiquette, diplomacy, envoy, pristavs, plenipotentiary powers 